\title{
IMPLEMENTASI E-LEARNING BERBASIS MOODLE DI MASA PANDEMI COVID 19
}

\author{
Kristina Sara ${ }^{1}$, Ferdinandus Lidang Witi ${ }^{2}$, Anastasia Mude ${ }^{3}$ \\ Universitas Flores, Indonesia ${ }^{1,2,3}$ \\ kristinasara27@ gmail.com ${ }^{1}$
}

\begin{abstract}
ABSTRAK
Penelitian ini bertujuan mengetahui hasil dari implementasi e-learning berbasis moodle. Jenis penelitian ini merupakan analisis deskriptif dengan distribusi frekuensi, yaitu menyimpulkan berdasarkan data-data yang didapat selama penelitian. Sampel penelitian sebanyak 71 orang. Hasil penelitian ditemukan bahwa terdapat 19,3\% mahasiswa yang menjawab sangat setuju; 61,5\% mahasiswa yang menjawab setuju; 16,4\% menjawab tidak setuju 2,7\% menjawab sangat tidak setuju menggunakan e-learning berbasis moodle pada saat pandemi Covid-19. Bagi beberapa mahasiswa yang menjawab tidak setuju dan sangat tidak setuju, itu diakibatkan karena mahasiswa yang bersangkutan belum memiliki laptop dan tempat tinggalnya jauh dari perkotaan. Simpulan, penggunanan $e$ learning berbasis moodle sangat tepat, guna mengatasi kegiatan pembelajaran yang dilakukan secara konvensional yang tidak dapat dilakukan akhibat pandemi covid 19 dan ketersediaan sarana dan prasana sangat di perluhkan agar capaian pembelejaran dapat diwujudkan.
\end{abstract}

Kata Kunci: e-Learning, Moodle

\begin{abstract}
This study aims to determine the results of the implementation of moodle-based elearning. This type of research is a descriptive analysis with a frequency distribution, namely concluding based on the data obtained during the study. The research sample was 71 people. The results of the study found that there were $19.3 \%$ of students who answered strongly agree; $61.5 \%$ of students who answered agreed; $16.4 \%$ answered disagree $2.7 \%$ answered strongly disagreed with using moodle-based e-learning during the Covid-19 pandemic. For some students who answered disagree and strongly disagreed, it was because the student concerned did not yet have a laptop and their place of residence was far from urban areas. In conclusion, the use of moodle-based e-learning is very appropriate, in order to overcome conventional learning activities that cannot be done due to the COVID19 pandemic and the availability of facilities and infrastructure is very much needed so that learning outcomes can be realized.
\end{abstract}

Keywords: e-Learning, Moodle

\section{PENDAHULUAN}

Virus Corona 2019 merupakan nama dari sebuah penyakit yang melanda di seluruh dunia sejak akhir tahun 2019. Penyakit virus korona ini lebih ramai disebut dengan Covid-19, yang merupakan singkatan dari Corona Virus Disease 
2019. Penyakit yang ditandai dengan demam, batuk, dan kesulitan bernapas ini pertama kali muncul di wilayah Wuhan, Ini merupakan salah satu penyakit yang diakibatkan oleh virus Korona, dimana pertama kali muncul di wilayah Wuhan, Cina di akhir tahun 2019. Covid-19 bersifat menular di antara binatang atau manusi dengan gejala awal berkisar antara 1-14 hari. Yang membuat penyakit ini makin berbahaya adalah adanya potensi kematian bagi pengidapnya. Dan dikarenakan cara penularannya yang sangat cepat dan mudah, maka potensi kematian yang besar juga tidak bisa dibantah. Untuk menghindari terjadinya penularan Covid-19 dikampus, maka dilakukan pembelajaran jarak jauh. Pembelajaran jarak jauh mendorong munculnya perilaku social distancing dan meminimalisir munculnya keramaian mahasiswa sehingga dianggap dapat mengurangi potensi penyebaran Covid-19 di lingkungan kampus (Firman \& Rahayu, 2020).

Covid-19 dianggap berbahaya ini bukan hanya dikarenakan dampaknya pada total kematian atau pun jumlah tertular yang sangat banyak. Namun juga dikarenakan dampak lain yang diakibatkan oleh Covid-19. Misalnya saja dampaknya terhadap pertumbuhan ekonomi suatu negara, dampaknya terhadap kehidupan sosial, dampaknya terhadap pariwisata, dan juga dampaknya terhadap pendidikan. Dalam bidang pendidikan, Covid-19 juga membawa peran besar. Banyak perubahan yang terjadi dikarenakan hal ini. Misalnya saja dalam sistem pengajaran yang biasanya dilakukan secara tatap muka langsung dengan mahasiswa, diganti dengan sistem pengajaran secara online. Mulanya sistem pendidikan di Indonesia menggunakan sistem bertatap muka langsung dan dilaksanakan di dalam sebuah ruangan kelas. Tetapi dengan adanya penyakit ini, sistem pembelajaran diterapkan melalui tatap muka secara tidak langsung. Artinya, pembelajaran dilakukan dengan menggunakan perangkat teknologi informasi. Dimana disebut dengan pembelajaran secara online, yang disebut juga dengan e-learning.

E-learning yang merupakan sistem pembelajaran online adalah pembelajaran yang dilakukan dengan menggunakan alat bantu. Alat pembelajaran jarak jauh sinkron yang inovatif memberikan pembelajaran alternatif, fleksibel, dan kaya peluang, yang sangat sesuai dengan tuntutan dan kebutuhan pelajar abad ke-21 (Y1ldiz et al., 2015). E-learning juga merupakan pembelajaran dengan menggunakan jasa bantuan perangkat elektronika (Rusman et al., 2012). Dimana itu memungkinkan suatu pembelajaran yang bisa terjadi tanpa harus bertatap muka di dalam sebuah ruangan kelas. E-learning merupakan pendekatan inovatif untuk mendistribusikan desain yang baik pembelajaran yang berpusat pada peserta didik, interaktif, dan pembelajaran untuk setiap orang, kapan saja dengan menggunakan atribut-atribut dan sumber-sumber dari bermacam teknologi digital selama materi pembelajaran tersebut cocok untuk pembelajaran terbuka, fleksibel, dan lingkungan pembelajaran (Maudiarti, 2018). Pemanfaatan e-learning dalam 
proses pembelajaran diharapkan bisa meningkatkan motivasi dan hasil belajar peserta didik (Rijal \& Sofiarini, 2019).

E-learning merupakan jaringan dengan kemampuan untuk memperbaharui, menyimpan, mendistribusi, dan membagi materi ajar atau informasi (Sara \& Mukminan., 2014). E-learning juga merupakan suatu sistem pendidikan modern dari konvensional ke dalam bentuk digital menggunakan internet atau media jaringan komputer lain (Inggriyani et al., 2019). Diperlukan adanya pembelajaran melalui e-learning adalah untuk mengatasi keterbatasan antara dosen dan mahasiswa dalam hal waktu ataupun kondisi tertentu yang tidak memungkinkan pembelajaran dilakukan secara tatap muka dikelas (Lestari \& Hamka, 2019). Pembelajaran yang dimungkinkan untuk terjadi ini diterapkan selama era pandemi Covid-19 sebagai pendukung agar sistem pendidikan di Indonesia tetap berjalan. E-learning diterapkan di segala jenjang. Mulai dari Sekolah Dasar, Sekolah menengah Pertama, Sekolah Menengah Atas, dan juga di jenjang perkuliahan. Berdasarkan penjelasan itu, diharapkan bahwa e-learning akan membawa banyak sekali keuntungan bagi sistem pendidikan.

Ada beberapa komponen yang perlu diperhatikan dalam penerapan $e$ learning, yaitu (1) menyiapkan konten yang sesuai dengan capaian pembelajaran; (2) menggunakan metode pembelajaran, dengan menyediakan contoh dan praktik untuk memudahkan dalam belajar; (3) menggunakan teks dan gambar dengan tampilan yang menarik serta mudah dibaca; (4) pembelajaran dapat dilakukan secara langsung dengan instruktur ataupun belajar secara individu; menyiapkan sumber belajar lain yang berhubungan dengan konten; (6) membangun wawasan bersama tentang penggunaannya, sehingga nanti bisa tercapai tujuan pembelajaran. Selain itu aspek tampilan antarmuka meliputi: (a) tampilan tema; (b) layout; (c) kualitas teks; (d) kualitas gambar; (e) kualitas animasi; (f) kualitas pertanyaan; (g) kualitas navigasi; (h) konsistensi navigasi; (i) spasi. Sedangkan, aspek pedagogi metodologi meliputi: (a) interaktivitas (b) kapasitas kognitif (c) strategi pembelajaran (d) kontrol pengguna (e) kualitas pertanyaan (f) kualitas umpan balik (Surjono, 2013).

Penerapan e-learning berbasis Moodle merupakan pembelajaran yang memanfaatkan perangkat teknologi informasi berupa komputer/laptop, handponen yang terhubung dengan jaringan internet. Moodle adalah salah satu Learning Management System (LMS) open source. LMS merupakan paket perangkat lunak yang digunakan untuk menyampaikan materi pembelajaran dan resources multimedia secara online berbasis web (Surjono, 2013). Moodle juga merupakan sebuah aplikasi Learning Management System (LMS) yang gratis dan dapat digunakan serta dimodifikasi oleh pengguna berdasarkan keinginaanya khususnya proses belajar mengajar (Bariyah \& Imania, 2018).

MOODLE (Modular Object-Oriented Dynamic Learning Environment) is a cloud-based media can be accessed via a computer or smartphone must be connected with the internet (Sari \& Setiawan, 2018). Di dalam e-learning berbasis 
Moodle tersedia bagian untuk memasukkan materi, diskusi, tugas, dan quis. Pengajar bisa mengatur waktu untuk mengaksesnya. Yang menjadi peserta kelas, itu merupakan mahasiswa yang sudah terdaftar dan sudah diberikan hak akses. Dengan memiliki hak akses, mahasiswa dapat mengakses semua aktivitas yang terdapat pada kursus tersebut berdasarkan pertemuan. Mahasiswa juga dapat berkomunikasi baik dengan pengajar atau sesama mahasiswa melalui menu chat atau menu forum yang telah siapkan oleh pengajar sebagai media komunikasi. Selain itu mahasiswa juga dapat mengakses materi yang disajikan, mengkontrol nilai mereka sehingga penilaian dapat bersifat objektif, serta mengupload tugastugas yang diberikan dalam bentuk file dan dapat diunduh oleh pengajar untuk diperiksa dan diberi penilai (Rizal \& Walidain, 2019). Ada beberapa fitur yang terdapat dalam moodle meliputi (1) course content management; (2) synchronous and asynchronous communication; (3) the uploading of content; (4) the return of students work; (5) peer assessment; (6) student administration; (7) the collection and organization of students grades; (8) online questionnaires; (9) online quizzes; and (10) tracking tools (Syamsuddin, et al., 2014).

Namun, sebagai sebuah sistem yang baru diterapkan, sangatlah penting untuk melihat perkembangannya di lingkungan tempat pendidikan berlangsung. E-learning tentunya membawa dampak yang sama dan juga berbeda dengan sistem tatap muka di ruang kelas yang pernah dilakukan sebelumnya. Karena itulah penelitian ini dilakukan untuk mengetahui hasil dari implementasi $e$ learning berbasis moodle di sebuah lembaga pendidikan, khususnya di program studi Sistem Informasi Universitas Flores pada mata kuliah bahasa pemrograman 1. Mata kuliah bahasa pemrograman 1 merupakan mata kuliah yang wajib ditempuh oleh mahasiswa. Fitur yang dibagikan di dalam kursus tersebut berupa file powerpoint, PDF, video dan juga link-link lain yang berkaitan dengan materi pada pertemuan tertentu. Sehingga membuat mahasiswa dengan mudah mengaksesnya. Menggunakan e-learning moodle dibutuhkan kemandirian dan keaktifan dari mahasiswa, sehingga bisa tercapai tujuan pembelajarannya. Seorang peserta didik dikatakan mempunyai kemandirian belajar apabila ia mempunyai keinginan sendiri untuk belajar, menyelesaikan masalah, dan bertanggung jawab dalam menyelesaikan kewajibannya sebagai peserta didik (Fitriasari et al., 2018). Kemandirian belajar menuntut tanggung jawab yang besar pada diri peserta didik sehingga peserta didik berusaha melakukan berbagai kegiatan untuk tercapainya tujuan belajar (Ashadii \& Suhaeb, 2020). Untuk lebih memperkuat pengetahuan mengenai materi yang diberikan, mahasiswa bisa mencari sendiri melalui fasilitas internet dan arahan dari pengajar. Proses pembelajaran yang berkualitas dan efektif adalah proses pembelajaran yang mampu menimbulkan prakarsa atau keinginan dan aktivitas belajar secara mandiri atau sering disebut dengan kemandirian belajar mahasiswa sehingga mahasiswa berhasil mencapai tujuan-tujuan belajar dan pembelajaran yang memiliki daya tarik yang tinggi atau berdaya tarik bagi mahasiswa (Ismaniati et al., 2015). 


\section{METODE PENELITIAN}

Penelitian ini merupakan penelitian deskriptif. Penelitian dilakukan pada mahasiswa program studi Sistem Informasi Universitas Flores yang mengikuti perkuliahan mata kuliah bahasa pemrograman 1 di semester genap 2019. Jumlah sampel sebanyak 71 orang. Pengumpulan data dilakukan dengan menggunakan angket dan wawancara.

\section{HASIL PENELITIAN}

Pembuatan angket menggunakan media google formulir. Penyebaran link angket kepada mahasiswa dilakukan melalui grup WhatsApp. Wawancara dilakukan melalui telepon ke mahasiswa, satu persatu. Tujuan penyebaran dari angket dan wawancara tersebut untuk memperoleh respon dari mahasiswa setelah mereka mengikuti perkuliahan bahasa pemrograman 1 melalui e-learning berbasis moodle.

Tabel 1. Hasil Analisis Angket dari Mahasiswa

\begin{tabular}{|c|c|c|c|c|c|}
\hline \multirow{2}{*}{ No } & \multirow{2}{*}{ Indikator } & \multicolumn{4}{|c|}{ Persetase \% } \\
\hline & & SS & $\mathbf{S}$ & ST & TS \\
\hline 1 & $\begin{array}{l}\text { Penerapan e-learning berbasis moodle } \\
\text { menyenangkan }\end{array}$ & 9,7 & 65,3 & 18 & 7 \\
\hline 2 & $\begin{array}{l}\text { Mudah mengakses materi di e-learning } \\
\text { berbasis moodle }\end{array}$ & 10 & 75 & 10 & 5 \\
\hline 3 & $\begin{array}{l}\text { Mudah mengirimkan tugas di e-learning } \\
\text { berbasis moodle }\end{array}$ & 8 & 75,3 & 10 & 6,7 \\
\hline 4 & $\begin{array}{l}\text { Dapat melihat nilai tugas dan quis di } e \text { - } \\
\text { learning berbasis moodle }\end{array}$ & 10,7 & 76 & 8 & 5,3 \\
\hline 5 & $\begin{array}{l}\text { Dapat belajar dari sumber lain di } e \text { - } \\
\text { learning berbasis moodle }\end{array}$ & 4,4 & 74,3 & 20,3 & 1 \\
\hline 6 & $\begin{array}{l}\text { Dapat berinteraksi dengan teman sekelas } \\
\text { melalui diskusi di e-learning berbasis } \\
\text { moodle }\end{array}$ & 9,7 & 65,3 & 18 & 7 \\
\hline \multirow[t]{2}{*}{ No } & Indikator & $\begin{array}{l}\text { Persetase } \\
\%\end{array}$ & & & \\
\hline & & SS & $\mathbf{S}$ & ST & TS \\
\hline 7 & $\begin{array}{l}\text { Dapat berinteraksi dengan dosen melalui } \\
\text { diskusi di } e \text {-learning berbasis moodle }\end{array}$ & 10 & 72,5 & 17,5 & 0 \\
\hline 8 & $\begin{array}{l}\text { Selalu mengakses } e \text {-learning berbasis } \\
\text { moodle dengan mudah }\end{array}$ & 6,9 & 72,1 & 18 & 3 \\
\hline 9 & $\begin{array}{l}\text { Dapat mengakses } e \text {-learning berbasis } \\
\text { moodle kapan saja }\end{array}$ & 8,1 & 85 & 6,9 & 0 \\
\hline 10 & $\begin{array}{l}\text { Membutuhkan paket data dalam } \\
\text { mengakses e-learning berbasis moodle }\end{array}$ & 70 & 26 & 4 & 0 \\
\hline 11 & Biaya paket data mahal harganya & 55 & 43 & 2 & 0 \\
\hline 12 & $\begin{array}{l}\text { Saya kekurangan biaya membeli paket } \\
\text { data }\end{array}$ & 57 & 40 & 3 & 0 \\
\hline 13 & Saya belum mempunyai labtop/komputer & 30 & 65 & 5 & 0 \\
\hline 14 & Saya tidak bisa mengakses $e$-learning & 10 & 20 & 70 & 0 \\
\hline
\end{tabular}


berbasis moodle

\begin{tabular}{clcccc}
\hline 15 & $\begin{array}{l}\text { Tempat tinggal saya belum ada jaringan } \\
\text { internet }\end{array}$ & 9 & 71,3 & 18 & 1,7 \\
\hline 16 & Jaringan internet tidak lancar & 11,9 & 65,3 & 16,8 & 6 \\
\hline 17 & $\begin{array}{l}\text { Saya harus mencari lokasi yang ada } \\
\text { jaringan internet untuk mengakses } e- \\
\text { learning berbasis moodle }\end{array}$ & 6 & 68,3 & 18,7 & 7 \\
\hline 18 & $\begin{array}{l}\text { Mengakses } e \text {-learning berbasis moodle } \\
\text { membuat saya stress }\end{array}$ & 20 & 30 & 46 & 4 \\
\hline $\begin{array}{l}\text { Mengakses } e \text {-learning berbasis moodle } \\
\text { memberikan wawasan tentang metode } \\
\text { pembelajaran }\end{array}$ & 10 & 75 & 15 & 0 \\
\hline 20 & $\begin{array}{l}\text { Saya sebelumnya pernah mengakses } e- \\
\text { learning berbasis moodle }\end{array}$ & 30 & 65,3 & 3,7 & 1 \\
\hline$\quad$ Rata-rata & $\mathbf{1 9 , 3}$ & $\mathbf{6 1 , 5}$ & $\mathbf{1 6 , 4}$ & $\mathbf{2 , 7}$ \\
\hline
\end{tabular}

Tabel 2. Hasil Wawancara dengan Mahasiswa

\begin{tabular}{clrl}
\hline No & \multicolumn{1}{c}{ Indikator } & \multicolumn{1}{c}{ Jawaban dari Responden } \\
\hline 1 & $\begin{array}{l}\text { Intensitas interaksi antar } \\
\text { mahasiswa dengan dosen dalam } \\
\text { proses pembelajaran e-learning }\end{array}$ & $\begin{array}{l}\text { Intensitas antar mahasiswa dengan dosen sering } \\
\text { terjadi, karena semua mahasiswa sudah bergabung } \\
\text { sebagai peserta mata kuliah dan sudah bergabung di } \\
\text { berbasis moodle }\end{array}$ \\
& $\begin{array}{l}\text { WhatsApp mata kuliah. Apabila mahasiswa } \\
\text { mengalami kendala, bisa bertanya melalui WhatsApp. } \\
\text { Tetapi ada beberapa mahasiswa yang kesulitan dalam } \\
\text { berinteraksi, dikarenakan belum ada jaringan internet } \\
\text { di lokasinya. }\end{array}$ \\
\hline 2 & $\begin{array}{l}\text { Kualitas interaksi antar mahasiswa } \\
\text { dengan mahasiswa berjalan baik } \\
\text { selama proses pembelajaran } \\
\text { learning berbasis moodle }\end{array}$ & $\begin{array}{l}\text { Interaksi antar mahasiswa dengan dosen terjalin baik, } \\
\text { karena semua mahasiswa sudah bergabung sebagai } \\
\text { peserta mata kuliah dan sudah bergabung di grup } \\
\text { mata kuliah. }\end{array}$
\end{tabular}

\begin{tabular}{|c|c|c|}
\hline 3 & $\begin{array}{l}\text { Kepuasan mahasiswa terhadap } \\
\text { pembelajaran e-learning berbasis } \\
\text { moodle }\end{array}$ & $\begin{array}{l}\text { Kebanyakan dari mahasiswa merasa puas dengan } \\
\text { penerapan e-learning berbasis moodle. Tetapi } \\
\text { kedepannya sebaiknya juga dilakukan dengan tatap } \\
\text { muka langsung dikelas. Dan ditemukan ada beberapa } \\
\text { mahasiswa yang belum memiliki komputer/laptop, } \\
\text { sehingga mahasiswa bersangkutan tidak bisa } \\
\text { langsung mempraktekkan secara langsung. }\end{array}$ \\
\hline 4 & $\begin{array}{l}\text { Mahasiswa } \\
\text { kemudahan dalam memalami } \\
\text { materi yang disampaikan selama } \\
\text { proses pembelajaran e-learning } \\
\text { berbasis moodle }\end{array}$ & $\begin{array}{l}\text { Mahasiswa merasa sangat mudah mengakses materi, } \\
\text { tugas, quis dan diskusi. Hanya ada beberapa } \\
\text { mahasiswa yang mengalami kendala dalam } \\
\text { mengakses e-learning berbasis moodle, di karenakan } \\
\text { mahasiswa tersebut tinggal di lokasi yang belum ada } \\
\text { jaringan internet. }\end{array}$ \\
\hline
\end{tabular}


Hasil penelitian sebagai berikut; 19,3\% mahasiswa yang menjawab sangat setuju; $61,5 \%$ mahasiswa yang menjawab setuju; 16,4\% menjawab tidak setuju 2,7\% menjawab sangat tidak setuju menggunakan e-learning berbasis moodle pada saat pandemi Covid-19. Bagi beberapa mahasiswa yang menjawab tidak setuju dan sangat tidak setuju, itu diakibatkan karena mahasiswa yang bersangkutan belum memiliki laptop dan tempat tinggalnya jauh dari perkotaan.

\section{PEMBAHASAN}

Hasil penelitian yang diperoleh, menyatakan bahwa penerapan e-learning berbasis moodle pada masa pandemi covid-19 sangat tepat. Mahasiswa dan dosen masih bisa melakukan pembelajaran, walaupun dilakukan secara jarak jauh atau tidak bertatap muka langsung dikelas. Ini dibuktikan dengan hasil 61,5\% mahasiswa yang merasa setuju menggunakan e-learning berbasis moodle pada saat pandemi Covid-19. Hasil penelitian ini sesuai dengan hasil penelitian lain yang memberikan hasil, antara lain (1) mahasiswa merasa tertarik dengan penerapan e-learning; (2) penerapan e-learning memudahkan mahasiswa dalam mengikuti perkuliahan; (3) penerapan e-learning dapat mencegah penularan covid-19 di kampus (Indrayana \& Sadikin, 2020).

Selain itu ditemukan juga beberapa kendala yang terjadi pada mahasiswa, terutama mahasiswa dari orang tua dengan keadaan ekonomi kurang mampu, yang mana belum mampu untuk membeli komputer/labtop serta pulsa data. Karena perkuliahan semester sebelumnya dilakukan dikampus dengan fasilitas tersedianya komputer untuk latihan. Hasil penelitian ini juga sama dengan hasil survey dari peneliti lain yang menyatakan bahwa 50\% mahasiswa yang belum mempunyai laptop, sebanyak $80 \%$ mahasiswa menyatakan susah mendapatkan sinyal dan boros penggunaan paket data ini disebabkan karena banyak mahasiswa yang tinggal jauh dari daerah perkotaan (Astini, 2020).

Penggunaan suatu media pembelajaran, memang membutuhkan sarana dan prasarana yang memadai, sehingga semua bisa berjalan sesuai dengan yang telah direncanakan. E-learning berbasis moodle bersifat open source, sehingga semua bisa mendapatkan dengan cara mendowload. Yang perlu persiapkan dari pihak penyelenggara pendidikan dalam penerapan E-learning berbasis moodle, antara lain: 1) memberikan pelatihan kepada tenaga pendidik yang akan menggunakannya; 2) menyiapkan Hosting; 3) menyiapkan tenaga teknisi/operator yang memahami hal tersebut. Bagi tenaga pendidik harus mau belajar menggunakannya dan bersedia menyiapkan materi serta bahan-bahan pendukung materi. Bagi peserta didik perlu menyiapkan komputer/laptop/Handponen yang terkoneksi dengan jaringan internet. Dengan tersedianya sarana dan prasarana, maka proses pembelajaran akan berjalan dengan baik. Capaian pembelajaran yang telah direncanakan akan terwujudkan. 


\section{SIMPULAN}

Penggunanan e-learning berbasis moodle sangat tepat, guna mengatasi kegiatan pembelajaran yang dilakukan secara konvensional yang tidak dapat dilakukan akhibat pandemi covid 19 dan an ketersediaan sarana dan prasana sangat di perluhkan agar capaian pembelejaran dapat diwujudkan.

\section{DAFTAR PUSTAKA}

Ashadii, N. R., \& Suhaeb, S. (2020). Hubungan Pemanfaatan Google Classroom dan Kemandirian terhadap Hasil Belajar Mahasiswa PTIK pada Masa Pandemi. Media Elektronik, 17(2), 46-51.

Bariyah, S. H., \& Imania, K. A. N. (2018). Implementasi Blended Learning Berbasis Moodle Pada Jurusan Pendidikan Teknologi Informasi. Jurnal Petik, 4(2), 106-113. https://doi.org/10.31980/jpetik.v4i2.10

Firman, F., \& Rahayu, S. (2020). Pembelajaran Online di Tengah Pandemi Covid19. Indonesian Journal of Educational Science (IJES), 2(2), 81-89. https://doi.org/10.31605/ijes.v2i2.659

Fitriasari, P., Tanzimah, \& Sari, N. (2018). KEMANDIRIAN BELAJAR MAHASISWA MELALUI BLENDED LEARNING PADA MATA KULIAH METODE NUMERIK. Al-Qalasadi: Jurnal Ilmiah Pendidikan Matematika, 4(1), 1-8. https://doi.org/10.32505/v3i2.1367

Indrayana, B., \& Sadikin, A. (2020). Penerapan E-Learning Di Era Revolusi Industri 4 . 0 Untuk Menekan Penyebaran. Indonesion Journal of Sport Science and Coaching, O(1), 46-55. https://onlinejournal.unja.ac.id/IJSSC/article/view/9847

Inggriyani, F., Fazriyah, N., \& Purbasari, A. (2019). Penggunaan E-learning Berbasis Moodle bagi KKG Sekolah Dasar di Kecamatan Lengkong Kota $\begin{array}{llll}\text { Bandung. } & \text { Jurnal } & \text { SOLMA, }\end{array}$ https://doi.org/10.29405/solma.v8i2.3695

Ismaniati, C., Sungkono, \& Dian, W. (2015). MODEL BLENDED LEARNING UNTUK MENINGKATKAN KEMANDIRIAN BELAJAR DAN DAYA TARIK DALAM PERKULIAHAN. JURNAL PENELITIAN ILMU PENDIDIKAN, 8(2), 19-27.

Lestari, A. S., \& Rijal Hamka, S. (2019). Analisis PIECES dalam Implementasi Kebijakan E-Learning di IAIN Kendari. MANAGERIA: Jurnal Manajemen Pendidikan Islam, 4(1), 103-125. https://doi.org/10.14421/manageria.2019.41-07

Maudiarti, S. (2018). Penerapan E-Learning Di Perguruan Tinggi. Perspektif Ilmu Pendidikan, 32(1), 51-66. https://doi.org/10.21009/pip.321.7

Rijal, A., \& Sofiarini, A. (2019). Pengembangan E-Learning Mata Kuliah Pembelajaran Matematika Sd Berbasis Aplikasi Moodle Di Pgsd. Jurnal Basicedu, 3(4), 2071-2082. https://doi.org/10.31004/basicedu.v3i4.266

Rizal, S., \& Walidain, B. (2019). Pembuatan Media Pembelajaran E-Learning Berbasis Moodle Pada Matakuliah Pengantar Aplikasi Komputer Universitas Serambi Mekkah. JURNAL ILMIAH DIDAKTIKA: Media Ilmiah Pendidikan Dan Pengajaran, 19(2), 178. https://doi.org/10.22373/jid.v19i2.5032 
Rusman, Kurniawan, D., \& Riyana, C. (2012). Pembelajaran Berbasis Teknologi Informasi dan Komunikasi (2nd ed.). PT. RAJAGRAFINDO PERSADA.

Sara, K., \& Mukminan. (2014). Pengembangan E-Learning Mata Kuliah Aplikasi Komputer Aplikasi 2. 1, 139-152.

Sari, P. A., \& Setiawan, A. (2018). The Development of Internet-Based Economic Learning Media using Moodle Approach. International Journal of Active Learning, 3(2), 100-109. http://journal.unnes.ac.id/nju/index.php/ijal

Suni Astini, N. K. (2020). Tantangan Dan Peluang Pemanfaatan Teknologi Informasi Dalam Pembelajaran Online Masa Covid-19. Cetta: Jurnal Ilmu Pendidikan, 3(2), 241-255. https://doi.org/10.37329/cetta.v3i2.452

Surjono, H. D. (2013). Membangun Course E - Learning Berbasis Moodle (2nd ed.). UNY PRESS.

Syamsuddin, I., \& min, A. (2014). Assessing Moodle as Learning Management System Platform for English Course Based TOEFL. International Journal of Computer Trends and Technology, 18(6), 276-279. https://doi.org/10.14445/22312803/ijctt-v18p158

Yıldız, E., Sarıtaş, M. T., \& Can ŞENEL, H. (2015). Examining the Attitudes and Intention to Use Synchronous Distance Learning Technology among Preservice Teachers: A Qualitative Perspective of Technology Acceptance Model. American Journal of Educational Research, 3(10A), 17-25. https://doi.org/10.12691/education-3-10a-3 